\title{
Jorge Luis Borges
}

\author{
John Wilkins' analytiske sprog
}

Jeg har konstateret, at artiklen om John Wilkins er blevet fjernet i den I4. udgave af Encyclopaedia Britannica. Denne udeladelse er berettiget, hvis vi tænker på artiklens trivialitet (tyve linjer med rene biografiske omstændigheder: Wilkins blev født i I6I4, Wilkins døde i I672, Wilkins var kapellan hos Prins Charles Louis; Wilkins blev udnævnt til rektor for et af kollegierne i Oxford, Wilkins var den første sekretær for Det Kongelige Akademi i London etc.); den er angribelig, hvis vi tager Wilkins' spekulative værk i betragtning. Han rummede en overflod af lykkelige kuriositeter: Han interesserede sig for teologi, kryptografi, musik, fremstilling af gennemsigtige bistader, en usynlig planets bane, muligheden af en rejse til månen, muligheden af og principperne for et verdenssprog. Dette sidste problem helligede han bogen An Essay Towards a Real Character and a Philosophical Language (6oo sider i stort kvartformat, I668). Vort nationalbibliotek har ikke nogen eksemplarer af denne bog; for at skrive denne note har jeg måttet konsultere The Life and Times of John Wilkins (I910) af P. A. Wright Henderson; Wörterbuch der Philosophie (1924) af Fritz Mauthner; Delphos (1935) af E. Sylvia Pankhurst; Dangerous Thoughts (1939) af Lancelot Hogben.

Alle har vi på et eller andet tidspunkt været nødsaget til at deltage i den slags uigendrivelige diskussioner, $i$ hvilke en dame, med et fyrværkeri af interjektioner og inkonsekvenser, forsikrer, at ordet luna [måne] er mere (eller mindre) udtryksfuldt end ordet moon. Ud over den indlysende observation, at enstavelsesordet moon muligvis er mere egnet til at repræsentere et meget simpelt objekt end tostavelsesordet luna, er det ikke muligt at føje noget til den slags diskussioner; bortset fra sammensatte ord og afledninger er alle verdens sprog (uden at ekskludere Johann Martin Schleyers Volapük og Peanos romantiske Interlingua) lige lidt ekspressive. Der er ikke en udgave af Det Kongelige Akademis Grammatik, som ikke betoner "det spanske sprogs misundelsesværdige skat af pittoreske, lyksalige og rigt udtryksfulde ord", men der er tale om rent praleri uden berettigelse. Imidlertid udarbejder samme Kongelige Akademi med nogle års mellemrum et opslagsværk, der skal definere disse ord som spanske... I det universelle sprog, som Wilkins opfandt i midten af det I7. århundrede, definerer hvert ord sig selv. Descartes havde allerede i et brev dateret november 1629 bemærket, at

Passage $47-2003$ 
vi gennem tallenes decimalsystem på bare en dag kan lære at opregne alle kvantiteter helt op imod uendeligt og skrive dem i det nye sprog, tallenes sprog; ${ }^{\text {I }}$ også han havde foreslået dannelsen af et analogt sprog, et alment sprog, som organiserede og omfattede alle menneskelige tanker. Omkring I664 gik John Wilkins i gang med dette arbejde.

Han opdelte universet i fyrre kategorier eller klasser, som så blev underinddelt efter forskel, og disse igen underinddelt $\mathrm{i}$ arter. Han gav hver klasse et enstavelsesord på to bogstaver; hver forskel en konsonant; hver art en vokal. For eksempel: de betyder element; deb, det første af elementerne, ilden; deba, en del af ildens element, en flamme. I Letelliers tilsvarende sprog (I850) betyder $a$ dyr; $a b$ pattedyr; $a b o$ kødædende; aboj kattefamilien; aboje kat, abi planteædende; abiv hestefamilien etc. I Bonifacio Sotos Ochandos sprog (I845); betyder imaba bygning; imaca bordel; imafe hospital; imafo lazeret; imarri hus; imaru bondegård; imedo stolpe; imede søjle; imego gulv; imela loft; imogo vindue; bire bogbinder; birer indbinde. (Denne sidste liste skylder jeg en bog trykt i Buenos Aires i I886: Kursus i Universalsprog af dr. Pedro Mata).

Ordene i John Wilkins' analytiske sprog er ikke klodsede og tilfældige symboler; hvert af bogstaverne, som danner dem, er betydningsfulde, på samme måde som den Hellige Skrift er det for kabbalisterne. Mauthner bemærker, at børn kunne lære dette sprog uden at vide, at det er artificielt; senere i skolen ville de opdage, at det også er en universel nøgle og en hemmelig encyklopædi.

Efter at have beskrevet Wilkins' fremgangsmåde må vi undersøge et problem, som det er umuligt eller svært at undgå: værdien af den tavle med fyrre kategorier, som ligger til grund for sproget. Lad os se nærmere på den ottende kategori, kategorien sten. Wilkins inddeler dem i de almindeligt forekommende (flint, grus, skifer), de sjældne (marmor, rav, koral), de kostbare (perle, opal), de gennemsigtige (ametyst, safir) og de uopløselige (stenkul, valkejord, arsenik). Næsten lige så foruroligende som den ottende er den niende kategori. Denne lader os vide, at metallerne kan være enten ufuldkomne (cinnober, kviksølv), kunstige (bronze, messing), afsondringer (spåner, rust) eller naturlige (guld, tin, kobber). Hvalen optræder i den sekstende kategori; den er en aflang fisk, som føder levende unger.

Disse tvetydigheder, unødvendigheder og dunkelheder minder om dem, som doktor Franz Kuhn tillægger en vis kinesisk encyklopædi med titlen De velgørende kundskabers himmelske emporium. På dens usandsynlige sider kan man læse, at dyrene opdeles i

(a) dem der tilhører kejseren 
(b) de balsamerede

(c) de dresserede

(d) pattegrise

(e) havfruer

(f) fabeldyr

(g) løse hunde

(h) dem som er inkluderet i denne klassifikation

(i) dem der skælver, som om de var gale

(j) dem som findes i store mængder

(k) dem som er malet med en ganske fin kamelhårspensel

(l) etcetera

(m) dem som lige har slået vasen itu

(n) dem som på afstand ligner fluer

Det Bibliografiske Institut i Bruxelles dyrker også kaos: Det har inddelt universet i IOoo underkategorier, hvoraf nummer 262 angår Paven; nummer 282 angår den romersk-katolske kirke; nummer 263 Herrens Dag; nummer 268 søndagsskolerne; nummer 298 mormonerne; og nummer 294 brahmanismen, buddhismen, shintoismen og taoismen. Det fraskriver sig ikke heterogene underinddelinger, for eksempel nummer I79: "Grusomhed mod dyrene. Beskyttelse af dyr. Duellen og selvmordet set fra et moralsk synspunkt. Forskellige laster og defekter. Forskellige dyder og fortrin.”

Jeg har nævnt vilkårlighederne hos Wilkins, hos den ukendte (eller apokryfe) kinesiske encyklopædi og Det Bibliografiske Institut i Bruxelles; der er tilsyneladende ingen klassifikation af universet, som ikke er tilfældig og baseret på formodninger. Grunden hertil er enkel:Vi ved ikke, hvad universet er. "Verden," skriver David Hume, "er måske en rudimentær skitse lavet af en eller anden barnlig gud, som opgav den på halvvejen, flov over dens ufuldstændige udførelse; den er blot en underordnet guds værk, som de mere magtfulde guder håner; eller den er den forvirrede frembringelse af en gammel og pensioneret gud, som allerede er død" (Dialogues Concerning Natural Religion, V, I779).Vi må gå endnu videre; vi må betvivle, at der er noget univers i den organiske, samlende betydning af dette ambitiøse ord. Hvis der er, må vi overveje dets hensigt; vi må overveje ordene, definitionerne, etymologierne, synonymerne i Guds hemmelige leksikon.

Det umulige $\mathrm{i}$ at gennemtrænge universets guddommelige skema kan imidlertid ikke afholde os fra at opstille menneskelige skemaer, også selv om vi er klar over, at de kun er foreløbige. Wilkins' analytiske sprog er ikke det mindst beundringsværdige af disse skemaer. De klasser og arter, som udgør det, er modsætningsfulde og vage; det indfald, at ordenes bogstaver indikerer inddelinger og underinddelinger er, 
uden tvivl, genialt. Ordet salmón [laks] siger os ingenting; zana, det korresponderende ord, definerer (for den, som er velbevandret $\mathrm{i}$ de fyrre kategorier og i kategoriernes klasser) en skællet fisk, der lever i floder og har rødligt kød. (Teoretisk set er et sprog, hvor betegnelsen for hvert væsen angiver alle detaljer af dets skæbne, fortidige og fremtidige, ikke utænkeligt).

Hvis vi ser bort fra håb og utopi, er de mest lysende ord skrevet om sproget de følgende af Chesterton: "Mennesket ved, at der i sjælen forekommer nuancer, som er langt talrigere og mere navnløse end farverne i en efterårsskov... Det tror alligevel, at disse nuancer i alle deres sammenblandinger og forvandlinger kan gengives med præcision af en vilkårlig mekanisme af grynt og piben. Det tror, at der fra det indre af en børsmægler faktisk kommer lyde, som gengiver hele den gådefulde hukommelse og alle begærets kvaler" (G. F. Watts, p. 88, 1904).

Noter

I. Teoretisk set er antallet af talsystemer uden grænser. Det mest komplekse (til brug for guder og engle) vil regne med et uendeligt antal symboler, et for hvert af de hele tal; det mest simple behøver kun to. Nul skrives o, en I, to Io, tre II, fire Iоo, fem IоI, seks IIo, syv III, otte Iо0о ... Det er Leibniz' opfindelse, som var inspireret (lader det til) af I Chings gådefulde heksagrammer.

"El Idioma analítico de John Wilkins” fra Otras inquisiciones (1952), oversat af Morten Søndergaard. Andre undersøgelser udkommer på Gyldendal $i$ 2004. 